\title{
TAX SIMPLIFICATION AND THE TAX REFORM ACT OF I969
}

\author{
LAURENCE N. WOODWORTH*
}

\section{INTRODUCTION}

To those of us who spend our time considering different possible tax revision measures, it becomes apparent after a time that "tax simplification" means quite different things to different people. Probably this should not be surprising since everyone tends to see this problem, like many others, from his own vantage point. While recognizing that any classification of tax simplification concepts is subject to challenge, I nevertheless have arrived at a tentative classification taking these different points of view into account.

First, to the ordinary taxpayers-especially those who try to make out their own tax returns-tax simplification (or the lack thereof) seems to be judged primarily on the basis of the difficulties they have in making out their tax returns, and in understanding the instructions that accompany it.

Second, to the tax practitioners, especially accountants and many practicing tax lawyers, tax simplification relates to the regulations, rulings, and, to some extent, the statute itself. Their judgment of the relative complexity of the tax laws seems to depend in large part upon the extent to which the regulations, rulings, and statutes are understandable to them, make sense, and do not involve too many difficult computations or determinations. It appears likely that much the same standards are used by the revenue agents in evaluating the complexity or simplification of the tax laws.

A third category tends to evaluate tax simplification in terms of the difficulty of the problems left for determination by the courts. This group undoubtedly includes not only the judges who are faced with the difficult problems, but also those practicing before the courts-both the representatives of the Government and those presenting the views of the taxpayers.

In the consideration of the Tax Reform Act of $1969,{ }^{1}$ it became apparent that there was still a fourth category of complexity in the tax laws which also is a matter of wide concern. I am referring here to the encouragement that some tax provisions provide for the use of complicated tax devices designed to avoid the substantial tax burdens generally imposed.

Still another concept of tax simplification may be expressed in terms of administrative problems presented to the Internal Revenue Service. In large part this

- Chief of Staff, Joint Committee on Internal Revenue Taxation.

1 Tax Reform Act of r969, Pub. L. No. 9r-172 (Dec. 30, r969). 
overlaps with many of the categories set out above but, again, represents an approach from a different vantage point.

It seems to me that no one of these concepts should be allowed to appropriate unto itself the exclusive title to "tax simplification." Instead it seems preferable to evaluate tax simplification from the viewpoint of all of these varied approaches, as well as of others which may not be expressed here.

I think it is clear that the main thrust of the Tax Reform Act of 1969 was not tax simplification. As a result, it probably would be undesirable to base any general judgment of the merits of this act entirely on the degree of tax simplification, or complexity, which the act provided. The initial impact of most significant tax measures generally is a concern over the unknown brought about by the new act and, therefore, a concern as to what appears to be the added complexity of the measure. Much of the initial concern in this regard usually is dissipated after regulations are issued, and tax practitioners find that many of what they thought were unanswered questions are dealt with explicitly in the regulations. In the interim, however, there inevitably is a period of turmoil, such as the one in which we currently find ourselves, and of uncertainty as to the exact meaning of new provisions.

While the principal thrust of the Tax Reform Act was probably increased equity rather than tax simplification, it nevertheless appears doubtful that the moniker of the "Lawyers and Accountants Relief Act" represents a fair description of its tax simplification impact. While the achievements of the Tax Reform Act in obtaining a fairer tax system have been widely discussed, the contribution that act made toward a simpler tax system for the average taxpayer has not obtained the same degree of publicity. This could well be due to the attention drawn to some of the more complicated provisions of the statute which the Congress believed were necessary in order to deal with the complex situations devised by highly sophisticated taxpayers, or at least for them by sophisticated tax practitioners. Later in this article I will illustrate some of the difficulties with which the Congress was confronted in meeting some of the more sophisticated tax avoidance techniques developed in recent years. The complexity in dealing with these problems in no small part is attributable to the complexity of the devices themselves. However, the problems were made more difficult by the overriding considerations of equity and economic and fiscal impact to which, in many cases, the Congress attached overriding importance.

While the Tax Reform Act undoubtedly added some areas of complication to the tax laws, generally these were added almost exclusively for those taxpayers in the upper income brackets who already have access to and make substantial use of well informed tax advisers. For those with moderate or low incomes, on the other hand, the Tax Reform Act should bring a substantial degree of tax simplification. This may not be realized immediately, however, since parts of these measures are put into effect gradually over succeeding periods up to and including the year 1973. Six 
such measures which bring substantial simplification for the average taxpayer are discussed below.

\section{I}

\section{The Tax Reform Act-Simplification for Those in the Middle and Lower Income Groups}

\section{A. A More Liberal Standard Deduction and Low-income Allowance}

The average taxpayer frequently finds the preparation of his tax return complicated because he must itemize his personal deductions for such items as state and local taxes, interest, charitable contributions, and medical expenses. Personal deductions are, of course, designed to make the income tax fairer. While there are differences of opinion as to the desirability of particular personal deductions, the objective of these deductions is to place the income of taxpayers in different situations on a more comparable basis by allowing certain expenses to be deducted before applying the tax rates. Nonetheless, large numbers of taxpayers find it difficult to compute the various personal deductions to which they are entitled by tax law. However, in I944, to simplify the preparation of individual income tax returns and the handling of these returns by the Internal Revenue Service, individuals were granted the option of taking a standard deduction amounting to ten per cent of adjusted gross income or $\$ \mathrm{I}, 000$, whichever is less, in lieu of itemizing the personal deductions to which they were otherwise entitled. And in I964, to aid low-income people, a floor was placed on the standard deduction by the adoption of a minimum standard deduction amounting to a flat $\$ 200$ plus an additional \$100 for each personal exemption up to a total of $\$$ I,000. 2

When the ten per cent standard deduction was first introduced in I944, it was highly successful in simplifying the preparation of tax returns for moderate-income people. Over eighty-two per cent of the total number of individual income taxpayers in that year chose the standard deduction; only about eighteen per cent of the total number of returns contained itemized deductions." However, over the years, the standard deduction became considerably less effective in achieving the desired tax simplification. Individuals became entitled to increasingly larger itemized deductions as a result of such factors as increased state taxes, increased interest charges for home ownership, higher medical expenses, generally rising price levels, and amendments to the tax laws liberalizing particular deductions. Faced with this increase in their itemized deductions and the fixed $\$ 1,000$ ceiling on the standard deduction, more and more taxpayers switched from the standard deduction to itemizing their deductions - on their tax returns. For I969, for example; it is estimated that the

\footnotetext{
${ }^{3}$ See INT. REv. CODE of $1954 \$ \$ \mathrm{I} 4 \mathrm{I}-45$. The maximum deduction is halved for married individuals filing separate returns ( $\$ \mathrm{r} 4 \mathrm{I}(\mathrm{a})$ ) and if such an individual elects the minimum standard deduction, he may only deduct \$100 plus his deductions for exemptions ( $\$$ I4I (c)(2)(C)). [The INI. REv. CoDE. of 1954 is hereinafter referred to as CoDE.]

${ }^{8}$ H.R. Rep. No. 4r3, 9rst Cong., Ist Sess., pt. I, at 201 (I969).
} 
percentage of returns with itemized deductions will rise to almost forty-two per cent of all returns, while returns with standard deductions will decline to about fifty-eight per cent of all returns. For that year, even in the relatively low-income levels between $\$ 3,000$ and $\$ 5,000$, as many as one-fourth of all returns are expected to contain itemized deductions; the standard deduction is expected to be taken in less than half the returns in the $\$ 7,000$ to $\$ 10,000$ income brackets, in only about one-fourth of the returns in the $\$ \mathrm{ro}, 000$ to $\$ 15,000$ income brackets, and in only a very small percentage of those with incomes of over $\$ 20,000 .{ }^{4}$

The Tax Reform Act of 1969 will reverse this trend toward the greater use of itemized deductions by increasing both the ceiling and the floor of the standard deduction. The maximum standard deduction is increased from its prior level of ten per cent of adjusted gross income with a $\$ \mathrm{r}, 000$ ceiling to thirteen per cent of adjusted gross income with a $\$ \mathrm{I}, 500$ ceiling in $\mathrm{I} 97 \mathrm{I}$, to fourteen per cent with a $\$ 2,000$ ceiling in 1972 , and to fifteen per cent with a $\$ 2,000$ ceiling in $1973 .^{5}$

In addition, the Tax Reform Act replaces the minimum standard deduction with a low-income allowance amounting to $\$ 1,100$ in $1970, \$ 1,050$ in 1971 , and $\$ 1,000$ in $1972 .{ }^{6}$ This decrease in the level of the low-income allowance is approximately matched by increases in the per capita exemptions in these years from the level of $\$ 600$ in 1969 to $\$ 750$ in $1973,{ }^{7}$ so that in 1970 and subsequent years the starting tax level is at least $\$ \mathrm{I}, 700$ for a single person.

Because of the pressing fiscal need for revenue in 1970 and 1971 , the low-income allowance is to be reduced in those years where individuals receive income in excess of nontaxable income levels. ${ }^{S}$ In 1972 and later years, the full low-income allowance applies without reduction for the size of income.

As a result, in 1973 , when the increased standard deduction and the low-income allowance will be fully effective, about eleven million tax returns, or thirty-five per cent of all those previously itemizing deductions, are expected to switch to the standard deduction. This should raise the total number of tax returns using the simpler standard deduction to fifty-five million, or seventy-three per cent of the total, compared with 20.6 million returns, or twenty-seven per cent of the total, which are expected to continue itemizing deductions. This increase in the standard deduction, including the low-income allowance, in the long run is expected to give

\footnotetext{
"These statistics are as reported in id. at 20x-02.

${ }^{5}$ Tax Reform Act of $1969, \S 802(b)$, amending CODE $\$ I_{4} \mathrm{r}(\mathrm{b})$.

- Tax Reform Act of 1969 , $\$ 802(\mathrm{c})$, amending CODE $\$ \mathrm{I} 4 \mathrm{I}(\mathrm{c})$.

${ }^{7}$ Tax Reform Act of 1969 , $\$ 80 x$, amending CoDE $\$ 151$.

${ }^{8}$ In 1970 the excess of the $\$ \mathrm{~T}$, roo minimum standard deduction over the prior law minimum standard deduction will be reduced by $\$ \mathrm{r}$ for every $\$ 2$ of income above the new nontaxable levels (i.e., $\$ 1,100$ plus $\$ 625$ for each exemption). Tax Reform Act of $1969, \$ 802$ (c) (3)(B), adding Codp $\$ \mathrm{r}_{4} \mathrm{x}(\mathrm{c})$ (3)(B). In 1971 the excess of the $\$ 1,050$ minimum standard deduction over the prior law standard deduction will be reduced by $\$$ I for every $\$ 15$ of income in excess of the new nontaxable levels (\$1,050 plus $\$ 650$ for each exemption). Tax Reform Act of $1969, \$ 802(c)(6)$, adding Code $\$ 14 \mathrm{r}(c)(6)$. See text aecompanying notes $25 \& 26$ infra for a fuller discussion of the reasons motivating the Congress to adopt this phaseout of the low-income allowance.
} 
about forty-three million taxpayers tax relief amounting to almost $\$ 3.7$ billion a year (in terms of 1969 income levels). ${ }^{9}$

\section{B. Removal of Large Numbers of Individuals from Tax Rolls}

While the chief motivation in the Tax Reform Act for taking a large number of persons off the tax rolls was to remove all tax burdens for those at or below the poverty levels, this also represents a significant tax simplification for those involved. This simplification results from the combined effect of higher personal exemptions, the larger standard deduction, and the new low-income allowance described above. To be more specific, the Tax Reform Act increases the per capita exemption level from $\$ 600$ to $\$ 625$ for 1970 (the exemption is increased to $\$ 65^{\circ}$ on July I, I970, for withholding tax purposes), to $\$ 65^{\circ}$ for I97I, to $\$ 700$ for I972, and to $\$ 75^{\circ}$ for 1973 and thereafter. ${ }^{10}$ By I973, as a result of higher personal exemptions and the lowincome allowance, a single person will remain nontaxable up to an income of $\$ 1,750$ compared with $\$ 900$ under prior law. Similarly, under the new law, a married couple will not incur tax liability until its income exceeds $\$ 2,500$, compared with $\$ \mathrm{r}, 600$ under prior law; for a married couple with two dependents, the nontaxable level is moved up to $\$ 4,000$ from $\$ 3,000$ under prior law. ${ }^{11}$

By 1973 when it will be fully effective, the increase in personal exemptions under the Tax Reform Act will provide over $\$ 4.8$ billion of tax relief ${ }^{12}$ and will make nontaxable 2.7 million returns which now incur tax liability. In addition, the increase in the standard deduction and the low-income allowance will make nontaxable 4.9 million tax returns. All in all, the Tax Reform Act will make nontaxable 7.6 million returns that were required to pay tax under prior law. ${ }^{13}$

\section{Raising Filing Requirements}

The Tax Reform Act not only relieves certain taxpayers of the obligation to pay income tax but also revises the requirements for filing tax returns to conform with these new higher levels of income at which individuals start to incur tax liability. Before that time, many persons who were not subject to the tax were required to file returns. Prior to the Tax Reform Act, individuals were required to file tax returns if their income exceeded $\$ 600$ (or $\$ 1,200$ for people over 65 years of age), even though

\footnotetext{
'These figures for the year 1973 are unpublished estimates prepared by the staff of the Joint Committee on Internal Revenue Taxation.

${ }^{10}$ Tax Reform Act of 1969 , $\$ 801$, amending CODE $\S \mathrm{r} 5 \mathrm{I}$.

${ }^{11}$ See Tax Reform Act of 1969, $\$ 801,802 \& 803$ (a), amending CODE $\$ \S I, 14 \mathrm{I}$ (c) \& I5I.

${ }^{13}$ Staff of Joint Comm. on Internal Revenue Taxation, 9ist Cong., ist Sess., Revenue Estiamates Relating to the House, Senate, and Conference Versions of H.R. I3270, Tax Reform Act OF 1969, at 2 (1969) [hereinafter cited as REvENUE Estimates].

${ }^{18}$ Id. at 10 . The split into 4.9 million returns made nontaxable by the increase in the standard deduction and the low-income allowance (estimated before the effects of the higher personal exemption), and the 2.7 million returns made nontaxable by the higher personal exemption are estimates made by the Staff of the Joint Committee on Internal Revenue Taxation.
} 
no tax was due. ${ }^{14}$ Under the Tax Reform Act, for 1970 , 1971, and 1972, a single person will not be required to file a tax return until his income exceeds $\$ 1,700$, while a married couple filing jointly will not be required to file a return until its income exceeds $\$ 2,300$. These amounts are increased $\$ 600$ for each additional personal exemption to which the taxpayer or the married couple filing jointly is entitled because of age. In 1973 and later years, when the tax relief provisions of the Tax Reform Act become fully effective, a return will not be required until income reaches $\$ 1,750$ for a single person, or $\$ 2,500$ for a married couple filing jointly. These amounts are increased by $\$ 75^{\circ}$ for each additional personal exemption because of age..$^{15}$

\section{Allowing More Taxpayers to Use the Optional Tax Table}

The Tax Reform Act also simplifies the tax law for taxpayers with incomes up to $\$$ ro,000 by allowing them to use the optional tax table. ${ }^{16}$ Under prior law, the use of this table was restricted to taxpayers with incomes of $\$ 5,000$ or less. This change will simplify the preparation of the returns for large numbers of individuals since it will permit more people to find the tax on their adjusted gross income directly from the optional table, instead of going through the computations of subtracting personal exemptions and deductions from adjusted gross income and applying the tax rates to the remaining taxable income.

\section{E. Computation of Income Tax by the Internal Revenue Service}

The Act also makes it easier for individuals to arrange to have their tax computed by the Internal Revenue Service on the basis of information supplied by the taxpayer. Under prior law, taxpayers could elect to have the Internal Revenue Service compute their tax only if their gross income was less than $\$ 5,000$, their income consisted of wages subject to withholding and no more than $\$ 200$ of dividends, interest, and nonwitheld wages, and they did not claim adjustments for sick pay, moving expenses, or itemize their deductions. ${ }^{17}$ The tax in these cases was computed from the optional tax tables and did not take account of the retirement income credit or whether the taxpayer was a head-of-household or surviving spouse. In addition, for purposes of making this tax computation, the minimum standard deduction was not available to married taxpayers filing separate returns.

The Tax Reform Act made several liberalizing amendments in this area. ${ }^{18}$ It raised the income limit at which a taxpayer may elect to have his tax computed by the Internal Revenue Service from $\$ 5,000$ to $\$ 10,000$. It also provides that the tax computation by the Internal Revenue Service is to take account of the taxpayer's

\footnotetext{
${ }^{14} \operatorname{CoDE} \S 6012(a)$.

${ }^{15}$ Tax Reform Act of $1969, \$ 94 \mathrm{I}$, amending CODE $\$ 6012(\mathrm{a})$.

${ }^{10}$ Tax Reform Act of $1969, \S 803$ (c), amending CoDE $\S 3$.

${ }^{17}$ CODE $\S$ Gor 4 (b).

${ }^{18}$ Tax Reform Act of 1969, $\S 942$, amending CODE $\S 601_{4}(\mathrm{~b})$.
} 
status as a head-of-household or surviving spouse. In addition, the Secretary of the Treasury by regulations is given the authority to provide that the Internal Revenue Service may compute the tax regardless of the source of the taxpayer's gross income, regardless of whether it is $\$ 10,000$ or more, and regardless of whether he itemizes his deductions or takes the standard deduction. Moreover, in this computation the retirement income credit may be taken into account in computing the tax. The extent to which this regulatory authority is used to achieve further simplification will, of course, depend on future action by the Internal Revenue Service.

\section{F. Allowing Nontaxable Individuals to Eliminate Withholding on Their Wages}

Prior to the Tax Reform Act, individuals, although having annual incomes too small to be subject to tax liability, nonetheless often had income tax withheld on their wages by employers. This, for example, could occur for individuals who do not work regularly throughout the year. Such withholding created hardships for the employees concerned since it deprived them of the use of the sums withheld until the refunds were received. It also created administrative problems for the Internal Revenue Service, which was required to make refunds. The Tax Reform Act makes it possible for such an employee to eliminate the overwithholding if (in accordance with regulations prescribed by the Internal Revenue Service) he certifies to the employer that he anticipates that he will incur no income tax liability for the current taxable year and that he incurred no tax liability for the preceding taxable year. ${ }^{10}$

\section{II}

Other Forms of Tax Simplification in the Tax Reform Act

While most of the tax simplification efforts in the Tax Reform Act were directed toward the middle and lower income taxpayer, this was not exclusively the case. The revision in the income averaging provision should be of assistance to the middle and upper income taxpayer and the tax practitioners who are likely to prepare their returns. Moreover, the Congress made a significant effort both to discourage the use of complicated tax devices and at the same time to encourage the receipt of earnings in the most customary form, namely, as ordinary income.

\section{A. Simplification for Taxpayers Who Average Their Incomes}

Taxpayers who elect to average their incomes under sections $1301-05$ of the Internal Revenue Code should find it much simpler to prepare their tax returns as a result of the Tax Reform Act of $\mathbf{1 9 6 9 .}$. This is because, in addition to making income averaging available to individuals whose income increases twenty per cent

\footnotetext{
${ }^{20}$ Tax Reform Act of 1969 , $\$ 805(f)$, adding CODE $\$ 3402(n)$.
} 
over the base period (as compared with $33^{1 / 3}$ per cent under prior law), the act extends income averaging to most forms of income for which it was not available before, namely, long-term capital gains ${ }^{20}$ as well as wagering income and income from gifts. Considerable simplification results from these changes because it is no longer necessary for the taxpayer to go through the computations required under prior law to separate these types of income from income eligible for averaging and to mesh the tax liability on capital gains under the alternative rate with the liability on income subject to averaging. While the new form for averaging has not as yet been prepared, it should be possible to eliminate at least twenty-five lines of computation which previously were required on the tax schedule dealing with averaging.

\section{B. The Fifty-Per-Cent Ceiling Rate on Earned Income: Reducing the Incentive to Seek Out and Develop Tax Loopholes}

For many years, the Congress has been concerned about attempts by individuals with large earned incomes to escape from the upper bracket regular individual income tax rates by seeking out and developing a series of tax preferences usually designed (in those cases where they were designed at all) to encourage some specific type of activity and not intended to be used in tandem with other tax preferences for other types of activity. Often these devices take the form of converting ordinary income into capital gains. Quite aside from their tax reduction aspects, these attempts have the effect of complicating the tax law: first, because the taxpayers who enter into these tax reduction transactions frequently require the aid of expensive legal and accounting talent; and second, because they make necessary complicated remedial legislation, regulations, rulings, and tax forms, which tend to affect not only the taxpayers directly concerned with tax avoidance attempts but many others as well.

The Ig69 Act, in several different ways, attempts to reduce the incentive for individuals with earned income to seek out a series of tax preferences, and at the same time to give these individuals greater incentives to concentrate their efforts on their work. One aspect of this effort is represented by the many changes made by the act in reducing or eliminating tax preferences.

The positive incentive effect is represented by the addition of a ceiling rate for earned income. Starting in 1972, a fifty-per-cent ceiling is placed on the marginal tax rate applying to an individual's earned income, ${ }^{21}$ which otherwise could be subject to a rate as high as seventy per cent. This fifty-per-cent rate ceiling generally applies to single individuals with taxable earned income in excess of $\$ 38,000$ under the new rate schedule for single persons and married couples with taxable earned incomes in excess of $\$ 52,000$ - since above these taxable income levels marginal tax rates

\footnotetext{
${ }^{20}$ If income averaging is elected by the taxpayer, the special $\$ 50,000$ alternative capital gains rate is not available. See Tax Reform Act of 1969 , $\$ 3 \mathrm{II}, 5 \mathrm{II}$, amending CODE $\$ \$ \mathrm{I201}, 1302$.

${ }^{31}$ Tax Reform Act of 1969 , $\$ 804$, adding CoDE $\$ 1348$. In 1971 the ceiling rate is $60 \%$.
} 
exceeding fifty per cent would otherwise apply under the regular rate schedule. To prevent the fifty-per-cent rate ceiling from benefiting those with large amounts of tax preferences and to discourage the use of such preferences, ${ }^{22}$ the amount of earned income eligible for this ceiling rate is reduced by tax preferences in excess of $\$ 30,000$.

In achieving tax simplification, the fifty-per-cent rate ceiling on earned income is intended to work hand in hand with the provision in the Tax Reform Act eliminating the alternative twenty-five-per-cent rate for those with capital gains in excess of $\$ 50,000$. $^{23}$ As a result of these two changes, an individual with large amounts of earned income in the topmost tax bracket, who also has large capital gains, can no longer look forward to reducing the marginal tax rate on his earned income by forty-five percentage points-from seventy per cent (the top marginal rate applicable to ordinary income) to twenty-five per cent (the alternative rate on capital gains) through converting ordinary income to capital gain. Instead, when the provisions of the act are fully effective, the difference between the marginal tax rates applying to his earned income and his capital gains would be cut to fifteen percentage points-from fifty per cent on his earned income to thirty-five per cent (the rate on half of long-term capital gains in excess of $\$ 50,000$ subject to the top seventy per cent rate) ${ }^{24}$ The Congress anticipated that such results would substantially reduce the search for tax preferences and would make life simpler, if perhaps less intriguing, for the individual taxpayer.

\section{III}

\section{Problems of Securing Simple Tax Laws}

As we have seen, the Tax Reform Act makes a substantial contribution toward tax simplification for the bulk of taxpayers who have small or moderate incomes, and some provisions, such as the fifty-per-cent rate ceiling on earned income, make a start on such simplification for high-income taxpayers. Yet there are many other provisions of this act affecting high-income taxpayers which undoubtedly add to the complexity of the tax laws. Why should this be so in view of the fact that tax simplification historically has been one of the major objectives of tax reform? Broadly speaking, the answer is that tax simplification is only one of a number of objectives that the legislator considers in adopting a tax statute. Often Congress gives objectives of equity and economic or fiscal effects priority over tax simplification. That undoubtedly was true in the case of many provisions in the Tax Reform

\footnotetext{
${ }^{23}$ See Tax Reform Act of $\mathrm{x} 969$, $\$ 30 \mathrm{r}-03$, adding CoDE $\$ \S 56-58$. Examples of tax preferences are benefits from capital gain, depletion, stock option, accelerated depreciation, and certain other provisions which lessen the tax burden.

${ }^{38} \mathrm{Tax}$ Reform Act of $1969, \S 5 \mathrm{Ir}(\mathrm{b})$, amending CODE $\$ \S \mathrm{I} 20 \mathrm{I}(\mathrm{b}),(\mathrm{c})$.

${ }^{34}$ In some cases this difference may be reduced to as little as 3.5 percentage points by the effect of the minimum tax and the effect of reducing income eligible for the $50 \%$ ceiling by tax preferences in excess of $\$ 30,000$.
} 
Act of I969. In some provisions, it was possible for Congress to secure beneficial results with regard to all or most of these considerations, including tax simplification. Frequently, however, this was not the case: for example, a provision which achieves greater equity and has desirable economic and fiscal effects may also be complicated. In such cases there is invariably a search for a simpler provision which will be just as effective in achieving the desired goals. However, it may not be possible to find a relatively simple solution that will be completely satisfactory in other respects. When this happens the legislator must decide which of the goals are paramount and which must give way in the interest of securing the desired over-all effects. Here, of course, judgments will vary. There is always the danger of making a provision unduly complex in an attempt to be precise in reaching for equity. On the other hand, a provision which appears general and simple, at least on the surface, may not be equitable. Often too, its consequences are not simple. Such stubborn problems may require the legislator to make a trade-off between the various objectives or goals of tax reform including tax simplification.

In addition, the underlying problems which give rise to the need for tax legislation are frequently complex, involving sophisticated taxpayers. Complex problems tend to lead to complex solutions. For example, the provisions in the Tax Reform Act which deal with restricted stock options, stock dividends, and corporate mergers are complex because the ways in which the underlying subject matter is treated by business also is complex. A similar observation could be made about a number of other provisions of the Act, such as the provisions relating to accumulation trusts, provisions relating to foundations and their substantial contributors, the new minimum tax on preference income, and the new real estate provisions. In all these cases, it would have been far simpler to leave the law as it was-to let sleeping dogs lie. However, if as was the case in the Tax Reform Act, the intent is to provide remedial legislation and at the same time to avoid punitive or unduly harsh action, fairly complex legislation is required.

A number of provisions in the Tax Reform Act which cut back on various preferences allowed under prior law are undoubtedly more complex than would otherwise be the case because they provide transition rules which allow the taxpayer (or perhaps an important segment of the economy) some time to adjust to the new treatment. Other transition rules are designed to prevent the change from having what many may consider to be retroactive effects.

Some of the tax relief provisions of the Act are also made more complicated by limitations designed to keep the revenue loss in the next few years from exceeding what can be afforded on fiscal and economic grounds. And finally, as background in evaluating the Tax Reform Act, it may be well to remember that despite the great interest in tax simplification, large numbers of taxpayers have always been willing to accept particular provisions which make the law more complex, if they deem these provisions to be equitable and to contribute to their well being-witness 
the general support for itemized personal deductions and the repeated rebuffs of past attempts to curtail these deductions.

\section{IV}

\section{Illustrattve Examples of the Interplay of Tax StMplification and Other Objectives in the Deveiopment of the Tax Reform Act}

Let me turn now to some illustrations of the conflict between the objectives of tax simplification on the one hand and one or more of the other objectives of the Tax Reform Act on the other. My first example, the low-income allowance, involves a conflict between tax simplification and fiscal or revenue consequences. Other examples cited involve conflicts between simplification and equity or economic considerations.

\section{A. The Low-Income Allowance}

I believe it is clear that revenue considerations were almost alone in leading Congress to add to the low-income allowance a complicated formula for phasing out the allowance for taxpayers with incomes above specified limits. However, concern with the complexity of this phaseout formula also led Congress to provide a means to relieve practically all taxpayers who use the allowance of the complications in preparing tax returns that one might expect to arise from this phaseout, and also to eliminate the phaseout entirely after a two-year period. It will be recalled that as a result of the phaseout, in 1970 , the low-income allowance is reduced by $\$ \mathrm{I}$ for every $\$ 2$ that the individual's income exceeds the nontaxable income limits, while in $197 x$, the low-income allowance is reduced by $\$ \mathrm{I}$ for every $\$ \mathrm{IS}$ in excess of the nontaxable limits. ${ }^{25}$

The Congress, of course, recognized that this phaseout complicated the tax law (and also raised questions as to the fairness of the treatment accorded taxpayers with incomes in the areas where the phaseout applied). It desired to put the low-income allowance into effect in 1970 because prompt tax relief for families living at or near poverty levels was deemed imperative. However, without the phaseout, the lowincome allowance involves an annual revenue loss in the neighborhood of $\$ 2$ billion, and the Congress did not believe that the fiscal and economic situation permitted such a large loss in revenue from this provision in 1970 and $197 \mathrm{r}$. Accordingly, as a practical matter, the Congress was faced with a choice-to adopt the low-income allowance with some limitation like the phaseout to prevent the revenue loss from being excessive in 1970 and $197 \mathrm{r}$, or to defer the entire low-income allowance provision until 1972 when more of the reform provisions would be in operation and also when the fiscal and economic situation would be likely to be more suitable for the larger revenue loss involved. Faced with this choice, the Congress decided in favor of limited tax relief starting in 1970 and adopted a low-income allowance

\footnotetext{
${ }^{35}$ See note 8 supra.
} 
with the phaseouts indicated above. These phaseouts reduce the revenue loss from the low-income allowance to $\$ 625$ million in 1970 and $\$ \mathrm{r} .6$ billion in $197 \mathrm{r}^{20}$

However, the Congress was also aware that, unless there were some way to shortcut the work of computing the low-income allowance with the phaseout, many eligible taxpayers with moderate incomes would find it difficult to take the allowance on their tax returns. Such a short-cut was found by making allowance for the low-income allowance, including the phaseout, in the new optional tax table, which was expanded to apply to taxpayers with incomes up to \$ro,000. Since the bulk of the taxpayers who will benefit from the new low-income allowance (or have incomes in the area of the phaseout) will use the optional tax table, the phaseout, despite its formidable appearance in the law, will not represent a major complication in the preparation of tax returns for the limited two-year period for which it is applicable.

\section{B. The Minimum Tax}

The minimum tax provided by the Tax Reform Act also illustrates the interplay of equitable, economic, and simplification considerations in the development of tax legislation. The history of this provision seems especially pertinent for tax simplification because in developing the final version of this provision, the Congress placed great emphasis on reducing the tax complications involved.

The minimum tax was adopted because significant numbers of taxpayers receiving large economic incomes were paying relatively little or no income taxes as the result of tax preferences. For example, it was pointed out that in 1964 , I54 individuals with adjusted gross incomes of $\$ 200,000$ or more paid no income tax. ${ }^{27}$ In other cases, taxpayers with economic incomes of $\$$ I million or more paid an effective tax amounting to less than five per cent of their income. The concept of the minimum tax is that the tax preferences remaining after the application of specific remedial provisions should be grouped together and subjected to a special tax to insure the payment of significant taxes on this economic income.

In the House-passed tax reform bill, the functions of the minimum tax were embodied in two separate provisions. The first was a limit on tax preferences which required individuals with more than $\$ \mathrm{ro}, 000$ of certain tax preferences to pay regular income taxes on at least half of their economic income (the sum of these preferences and their income from taxable sources). ${ }^{28}$ The second provision required taxpayers with more than $\$ 10,000$ of tax preferences to allocate personal deductions between taxable income and the tax preferences that remained after applying the limit on tax preferences. ${ }^{20 .}$ This, in effect; disallowed the deductions allocated to the tax preferences.

\footnotetext{
${ }^{2 \dot{a}}$ ReVENOE EstTMates, sipra note I2, at 2.

${ }^{27}$ H.R. REP. No. I43, supra note 3 , at 9 .

${ }^{28}$ H.R. I3270, 9rst Cong., Ist Sess. $\$ 30$ r (1969).

${ }^{29} \mathrm{Id} . \$ 302$.
} 
The Senate Finance Committee substantially revised the House approach, replacing the two provisions (the limit on tax preferences and the allocation of deductions) with one minimum tax, a five per cent tax on selected preference items after subtracting a $\$ 30,000$ specific exemption. ${ }^{30}$ The scope of the tax was expanded to cover corporations as well as individuals. At the same time, the list of items treated as tax preferences for purposes of the minimum tax was expanded in some ways to cover additional items, including preferences received by corporations, ${ }^{31}$ and reduced in other respects by deleting certain items taken into consideration in the House bill, such as the interest income from state and local bonds ${ }^{32}$ and the appreciation in the value of charitable contributions taken as tax deductions. ${ }^{33}$

The Finance Committee revision was motivated by a number of considerations other than tax simplification. For example, the tax was extended to corporations rather than confined solely to individuals (as under the House bill) because it was deemed desirable to require corporations as well as individuals to pay tax on their preferences. Also, state and local bond interest was deleted from the scope of the minimum tax primarily in response to the widespread objections raised by the state and local governments that the taxation would add to their financing problems. Nonetheless, the desire on the part of the Congress to have the minimum tax in a form which would be relatively simple played an important part in determining the Finance Committee's action. The inclusion in the House provisions of certain items, such as appreciation in value of property deducted as a charitable contribution, especially had the effect of complicating these provisions. As a result of the interaction of the limitations applying to these items under the regular income tax and under the limit on tax preferences and allocation of deductions, the taxpayers involved would have been required to use simultaneous equations in order to compute the allocation of deductions and the allowable deduction under the regular income tax. The Congress was unwilling to see this type of complexity added to the tax return. Even if such mathematical problems could have been resolved, the Finance Committee regarded the use of two provisions-the limit on tax preferences and the allocation of deductions-to carry out the functions of a minimum tax as cumbersome in itself. It therefore desired to replace these two provisions with a single, simpler provision.

The Senate accepted the Finance Committee's version of the minimum tax with two major changes: first, in addition to the $\$ 30,000$ exemption provided by the Finance Committee, the taxpayer was permitted to deduct his federal income tax payments from the base of the minimum tax. ${ }^{34}$ This deduction for federal income taxes was adopted on the ground that those who pay substantial amounts of regular

\footnotetext{
${ }^{30}$ S. REP. No. 552, gIst Cong., Ist Sess. II2 (I969).

${ }^{31}$ Id. at II3-15.

ss $7 d$. at $217-\mathrm{rg}$.

${ }^{33}$ Id. at $80-82$.

${ }^{84}$ Senate-passed substitute version of H.R. 13270, 9Ist Cong., Ist Sess. $\S 30 I$ (I969).
} 
income tax should not have to bear the same minimum tax on their preferences as those whose regular federal income tax payments are small. And second, the Senate raised the rate of the minimum tax to ten per cent and made some revisions in the items treated as tax preferences for purposes of the tax. ${ }^{35}$

Although some changes were made in conference, the provision finally enacted into law closely resembles the version passed by the Senate. It is interesting to note that the relatively simple version of the tax finally enacted into law is expected to produce more revenue in the long run than the complex version first considered by the Congress-an estimated $\$ 635$ million a year compared with an estimated $\$ 555$ million a year. ${ }^{36}$

\section{Other Illustrative Examples}

Similar illustrative examples as to how tax simplification objectives are affected by equitable, economic, and fiscal considerations can be picked almost at random from the large number of provisions in the Tax Reform Act. Take, for example, the provisions in that act relating to bad debt reserves of financial institutions. ${ }^{37}$ These provisions were undoubtedly made more complex by a requirement that mutual savings banks must invest specified percentages of their assets in residential real estate if they wish to receive special tax treatment with regard to bad debt reserves; however, the Congress believed that there was an overriding consideration in the need to encourage investment in residential property. It also desired to conform the treatment of mutual savings banks with savings and loan institutions, which were already required to invest specified percentages of their assets in residential real property to obtain the special treatment for their bad debt reserves.

Another example is provided by the real estate provisions of the 1969 Act which generally withdraw accelerated depreciation from real property other than residential housing and tighten the recapture rules applying when property is sold. ${ }^{38}$ These provisions involve somewhat complicated rules because as an overriding consideration it was deemed necessary to grant relief in the form of more lenient recapture rules for residential housing and in the deferral of gain in the case of sales of certain low-cost government aided housing in order to stimulate investment in such properties.

\section{Conclusion}

These examples of the evolution of some of the provisions in the Tax Reform

\footnotetext{
${ }^{36}$ Id. A comparison of the House-passed limit on tax preferences and allocation of deductions with the Senate-passed version of the minimum tax, as well as the version aecepted by the House-Senate conferces, is contained in H.R. REP. No. 782, 9Ist Cong., Ist Sess. 301-02.

${ }^{86}$ ReVEnUe Estimates, supra note $\mathrm{I2}$, at 9 . The estimate of $\$ 555$ million of annual revenue gain under the early version of the minimum tax includes the revenue derived from both the limit on tax preferences and allocation of deductions.

87 Tax Reform Act of $1969, \$ 43 \mathrm{I}$, adding CoDe $\$ \$ 585-86$.

ss Tax Reform Act of 1969 , $\$ 521$, amending CODE $\$ \S 167(j),(k), 1250(a)$.
} 
Act illustrate how tax simplification objectives may be affected by equitable, economic, and fiscal considerations. They show that it would be a mistake to conclude that each and every provision of the tax law can be simple if attention were only paid to this objective. In a complex society, complicated tax provisions are sometimes required to obtain desirable equitable, economic, and fiscal effects, especially where the institutions involved engage in complicated transactions.

But if it is wrong to conclude that each and every provision in the tax law should contribute to simplification if only we put our minds to the task, it would also be wrong to conclude that new tax provisions must inevitably add to the complications. Although it contains complex tax provisions for higher income taxpayers with complex affairs, the Tax Reform Act of 1969 has simplified the tax system for the vast majority of taxpaying individuals. These are the individuals who will use the new optional tax table which has been expanded to the $\$ 10,000$ level, who will use the liberalized standard deduction which will in a few years rise to fifteen per cent of adjusted gross income or $\$ 2,000$, and who benefit from the new higher per capita exemption levels and the new low-income allowance.

In addition, the reform provisions in the Act, such as the fifty-per-cent ceiling on the marginal tax rates applicable to earned income, are likely to contribute to tax simplification to the extent that they discourage taxpayers from engaging in complicated transactions in an attempt to find tax shelters.

Tax simplification is a long-run objective. The Tax Reform Act did not solve all our tax problems and no one, least of all the Congress that passed the act, regards it as an end-all to all our problems. Work is now progressing at technical levels on a nonpartisan "deadwood bill" which has as its objective the removal from the Internal Revenue Code of obsolete provisions which have little or no application at the present time and which merely clutter the Code. The future will undoubtedly see other tax legislation bearing on tax simplification in the continuing effort to improve the tax laws. 